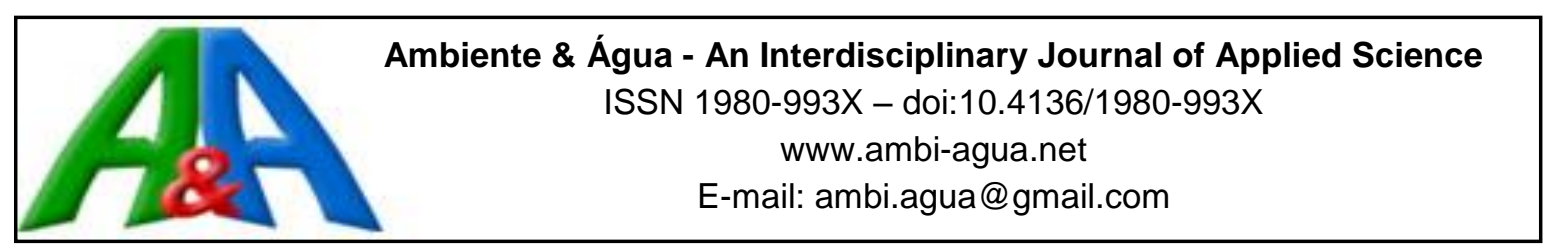

\title{
Energy management: a synthesis of scientific publications on biodigestion for waste management
}

\author{
doi:10.4136/ambi-agua.1911
}

Received: 04 Apr. 2016; Accepted: 24 Aug. 2017

\section{Marcia Aparecida Andreazzi*; Adriano Rogério Mendes; Karina Volpe de Oliveira; Maria de los Angeles Perez Lizama}

\author{
Centro Universitário de Maringá (UNICESUMAR/ICETI), Maringá, PR, Brasil \\ Programa de Pós-Graduação em Tecnologias Limpas e Curso de Medicina Veterinária \\ E-mail: marcia.adreazzi@unicesumar.edu.br, adriano_sumagro@hotmail.com, \\ karina.volpe@hotmail.com, maria.lizama@unicesumar.edu.br \\ *Autor correspondente
}

\begin{abstract}
Environmentally friendly options for waste disposal and the need for expansion and diversification of the national and international energy matrix are relevant issues today. One technique that supports these goals is anaerobic biodigestion, which generates clean energy from biomass. Accordingly, our goal was to perform a quantitative and qualitative assessment of scientific publications on biodigestion in order to understand the evolution of the technique, which is essential for environmental and economic sustainability. Ninety-nine articles indexed in the Scientific Electronic Library Online between 1980 and 2015 were evaluated. The results showed a significant increase in scientific publications since 2000 which addressed, in addition to environmentally friendly waste management, the energy issue, with the use of biogas. This increase in the number of publications coincides with increased awareness on natural resource management and concern about global energy management. Most of the articles involved a general evaluation of the process, using mainly animal waste from pigs, and emphasizing biodigestion as waste management, since pig farming produces a large volume of waste and has a high environmental impact.
\end{abstract}

Keywords: anaerobic fermentation, biogas, energy, brazilian scientific publications, waste management.

\section{Gestão energética: uma síntese dos indicadores quantitativos sobre biodigestão}

\section{RESUMO}

Opções ambientalmente corretas de destinação de resíduos e a necessidade de ampliação e diversificação da matriz energética nacional e internacional são assuntos pertinentes na atualidade. Uma das técnicas capaz de atender estas premissas é a biodigestão anaeróbica, que gera energia limpa a partir de biomassa. Desta forma, o objetivo deste trabalho foi realizar uma avaliação quanti e qualitativa sobre o tema biodigestão, entendendo o comportamento científico das publicações sobre esta técnica, fundamental para a sustentabilidade ambiental e econômica. Foram avaliados 99 artigos da publicação científica nacional, indexados na Scientific Eletronic Library Online, entre os anos de 1980 a 2015. Os resultados mostraram um aumento expressivo 
nas publicações científicas a partir de 2000, que abordavam, além da gestão de resíduos ambientalmente correta, a questão energética, com o uso do biogás. Este aumento nas publicações coincide com a maior conscientização acerca dos cuidados com os recursos naturais e a preocupação com a gestão energética mundial. A maioria dos artigos discutiu sobre a avaliação geral do processo, empregando dejetos animais, principalmente de suínos, enfatizando a biodigestão como gestão de resíduos, visto que a suinocultura gera um grande volume de dejetos e ocasiona elevado impacto ambiental.

Palavras-chave: biogás, energia, fermentação aneróbica, manejo de dejetos, publicações científicas brasileiras.

\section{INTRODUCTION}

Considering the search for environmentally friendly waste disposal options and the need for expansion and diversification of the Brazilian energy matrix, the use of clean energy derived from biomass is a current and important theme. Anaerobic biodigestion is one of the techniques capable of meeting these goals.

Several authors (Lucas Junior and Amorim, 2005; El-Mashad and Zhang, 2010; Orrico et al., 2016) commented on the need to implement techniques aimed at minimizing environmental impacts caused by waste and rationalizing energy use, and highlighted the anaerobic biodigestion, which has the advantages of producing biogas and biofertilizer, and reduces the pollution of water resources.

The use of biodigesters has shown considerable socio-economic benefits worldwide, especially the United States, Canada, China, India (Palhares, 2008) and Europe (Raboni and Urbini, 2014).

An examination of current publications on anaerobic biodigestion will allow a better understanding of the direction of current research on the subject, as well as the objectives and the main substrates used. There are several quantitative techniques used to evaluate publications (Vanti, 2002). In this context, scientometrics enables the analysis of the importance of a subject, author, and work, and evidences the tendencies and contributions of a certain topic, researcher or group of researchers, institution or country (Strehl and Santos, 2002). Indices, such as the frequency of articles and the impact factor of journals and where they are published are also used as scientiometric tools.

This study therefore used scientiometrics to conduct a quantitative and qualitative evaluation and an annotated synthesis of publications relating to biodigestion, to promote a better understanding of this technique, which is important in waste management and energy production, and is fundamental for environmental and economic sustainability.

\section{MATERIAL AND METHODS}

This is a scientometric study of the national scientific literature and an annotated synthesis of publications regarding the use of the biodigestion technique in Brazil. The objects of analysis were scientific articles published in journals indexed in the databases of the Scientific Electronic Library Online (SciELO), available in the Virtual Library through the website http://www.scielo.org. The present research was conducted according to Braun and Schubert (1988) methodological recommendations for scientometric studies.

The search for the scientific articles was performed from September 2015 to March 2016 with the use of the descriptors: "biodigestor", "biodigestion", "biogas" and "anaerobic digestion", yielding 33, 31, 82 and 5 articles, respectively. The search process at first allowed the identification of 151 scientific articles. Next, the scientific papers were selected through the evaluation of the titles and abstracts and the inclusion criterion related to the use of the 
biodigestion technique in Brazil as a form of waste treatment or as source of biogas, energy and/or biofertilizer. Thus, of the total of 151 articles, 52 articles were repeated or were considered to be unrelated to the focus of the research, which resulted in 99 articles.

After evaluation and critical analysis of the 99 articles that met the selection criteria, the following information was collected: year of publication of the article, allowing an assessment of the number of articles published per year; the central theme of the research, that is, the purpose of the work; substrate used in the process; city and state of origin of the main author of the paper; and the classification of the journal in the area of Environmental Science in 2014 according to WebQualis. Data were tabulated and organized in Microsoft Excel 2010 spreadsheets and a descriptive analysis of the data was performed.

\section{RESULTS AND DISCUSSION}

The qualitative and qualitative study on biodigestion involved publications from 1985 (Figure 1). These results demonstrated that, from the year 2000, studies on the use of animal and plant waste for energy production were the focus of Brazilian and world energy management. The results showed a peak of scientific publications in the period from 2009 to 2015, although the last sampling period did not include the year 2016.

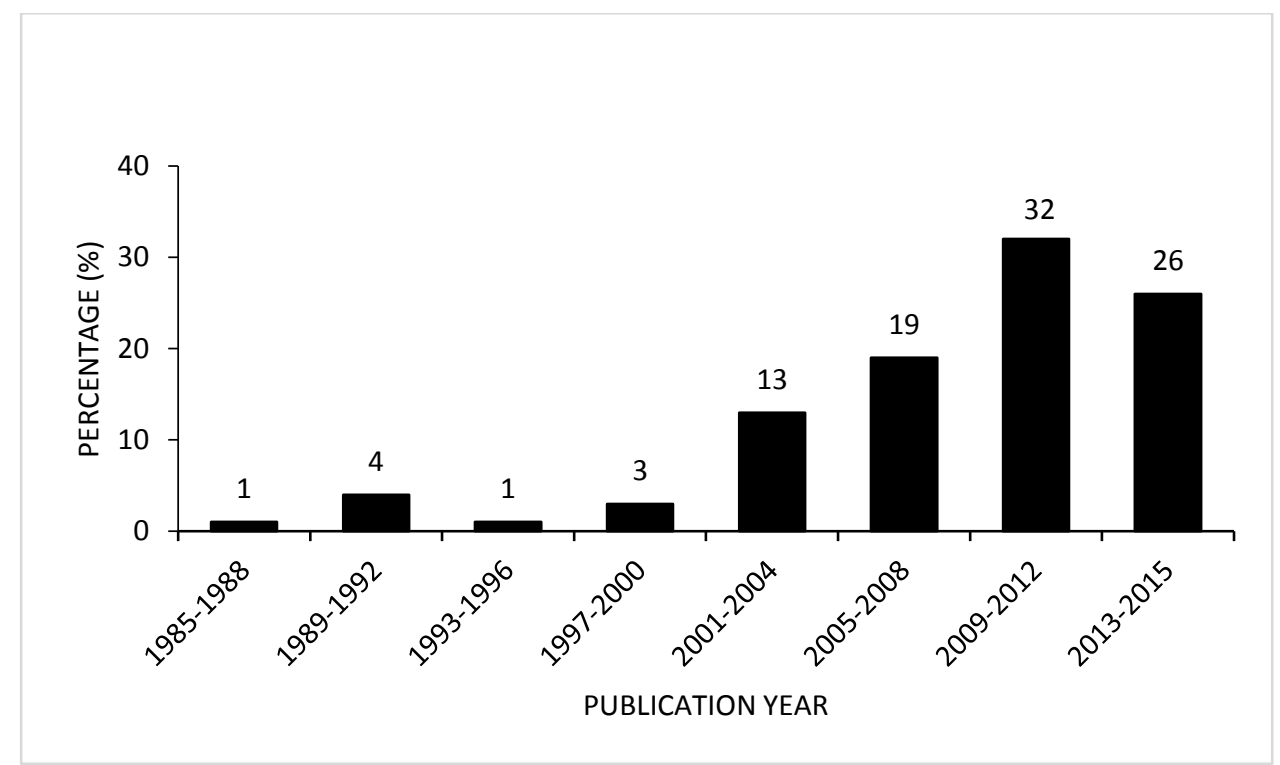

Figure 1. Number and percentage of scientific articles published in Brazil on the subject of biodigestion between 1985 and 2015.

Source: Capes (2015).

The first work related to biodigestion was carried out by Sawazaki et al. (1985), who discussed the potential of rice husk for the production of biogas through the action of alkaline hydrolysis. The 1990s was a transition period, in which the focus came to be biodigestors (Alta and Frios, 1992; Prada et al., 1998), biogas (Lacerda et al., 1990) and anaerobic biodigestion (Manfron, 1991). After this period, the number of studies increased sharply.

Considering that "biogas" was the most listed among the descriptors used in the search, and, associated with this fact, the increasing number of publications in the last decade, it is believed that these data illustrate, among other points, the current concern with the national energy issue. Basso et al. (2010) stated that awareness of the importance of the environment has encouraged the study of new renewable and less-polluting energy sources. 
Following this reasoning, Rocha et al. (2013) stated that the resources currently used for energy purposes include coal, natural gas and oil, and that, either by depletion of reserves or by harmful effects on the environment, the search for "energy security" and for renewable energy sources has become essential.

Raboni and Urbini (2014) analyzed the production and use of biogas in the European Community and demonstrated that the practice is common, using anaerobic digestion for gas production, aiming at reducing the use of landfills. The authors stated that Germany is the country that most produces biogas using this method. The use of this product is mainly for the production of energy (electricity and heat), or biomethane for use in vehicles. To this end, the European community has been adopting a series of measures since 2000 to reduce carbon dioxide emissions by $60 \%$ by 2050 ; measures such as the Green Paper, which will reduce the use of fossil fuels by $20 \%$ per year with the use of renewable energy (Raboni et al., 2015).

According to Oliveira et al. (2010), developed countries employ the generation of electricity through biogas, as confirmed by Raboni and Urbini (2014) and Raboni et al. (2015). According to the authors, in Brazil, there is a need for studies and technical and economic analyses that prove its efficiency. The feasibility of biogas is related to the use of technologies and research. To this end, incentives and the strengthening of regulations and public policies may contribute to making biogas a viable alternative (Gomes et al., 2014), following the steps of the European Community.

The result in relation to the thematic axis showed a large variation in the research objectives (Table 1). The studies evaluated economic efficiency, the use of the technique testing different substrates, models of biodigesters, evaluations of the products generated, type, quantity and quality and even literature reviews. Within these parameters, it is possible to highlight the articles that evaluated the general biodigestion process, using waste from animal husbandry such as beef cattle, dairy cows, sheep, goats, broilers, laying hens, horses and pigs, as well as the use of biodigestion as a form of treatment of effluents and agro-industrial residues, including effluents from slaughterhouses, dairy plants, starch-manufacturing plants, vinasse, coffee wastewater, banana farming, rice husk and crude glycerin.

Table 1. Number $(\mathrm{N})$ and percentage $(\mathrm{P})$ of scientific articles on biodigestion published in Brazil, according to the thematic axis, between 1985 and 2015 .

\begin{tabular}{lcc}
\hline \multicolumn{1}{c}{ Thematic axis } & $\mathrm{N}$ & $\mathrm{P}(\%)$ \\
\hline $\begin{array}{l}\text { Evaluation of the health aspect, aiming at the elimination of pathogens from } \\
\text { the residues }\end{array}$ & 29 & 29.30 \\
General evaluation of the process, using animal waste & 27 & 27.27 \\
Treatment of effluents and waste from agro-industry & 11 & 12.50 \\
Study of the production of biogas, methane and energy & 10 & 10.10 \\
Use of biofertilizer & 8 & 8.08 \\
Use of effluent & 8 & 8.08 \\
Evaluation of the process of biodigestion and elimination of hydrogen sulfide & 4 & 4.04 \\
Study of the equipment, reactor and/or design of the biodigester & 1 & 1.01 \\
Economic evaluation of biodigestion & 1 & 1.01 \\
Literature review of biogas, biofuels and/or renewable energies & 29 & 29.30 \\
\hline Total & $\mathbf{9 9}$ & $\mathbf{1 0 0 . 0 0}$ \\
\hline
\end{tabular}


Kunz and Oliveira (2008) stated that the goal of biodigestors in Brazil is: the treatment of effluents, use of biogas as an energy alternative, and the use of effluent to improve soil fertility. The use of these effluents to recover water and improve fertility was also an objective described by Leal et al. (2010) and Bócoli et al. (2016).

Silva (2012) concluded that biodigestion of human and swine waste was feasible, reducing BOD, COD and coliform levels; however, the treated effluent cannot be directly discharged in water bodies, without prior clearance. These measures are extremely important to maintain water quality in the environment, reducing environmental impacts, the basis for sustainable development.

Most of the analyzed articles correspond to the area of biodigestion with animal waste. In addition, several studies carried out with agro-industrial residues and biogas production are linked to the animal production chain, as well as its sanitary evaluation. For this reason, analyzing the biodigestion and animal production chain, the total number of articles $(n=61)$ was classified according to the animal species and the material used as substrate (Table 2).

Table 2. Number $(\mathrm{N})$ and percentage $(\mathrm{P})$ of scientific articles on biodigestion in Brazil between 1985 and 2015, according to the substrate of animal origin.

\begin{tabular}{llcc}
\hline Animal & Substrate & $\mathrm{N}$ & $\mathrm{P}(\%)$ \\
\hline Poultry & Broiler waste & 3 & 4.92 \\
& Slaughterhouse effluent & 1 & 1.64 \\
& Poultry litter & 1 & 1.64 \\
& Laying hen waste & 2 & 3.28 \\
Pigs & Waste & 28 & 45.90 \\
Beef cattle & Waste & 12 & 19.67 \\
Dairy cows & Waste & 2 & 3.28 \\
& Dairy plant waste & 2 & 3.28 \\
Goats & Waste & 3 & 4.92 \\
& Goat and sheep waste & 1 & 1.64 \\
$\begin{array}{l}\text { Equine } \\
\text { No identification of animal waste or biodigestion carried out with } \\
\text { mixed waste }\end{array}$ & 3 & 1.64 \\
\hline Total & Wood shaving with waste & $\mathbf{6 1}$ & 4.92 \\
\hline
\end{tabular}

All productive activity has an impact on the environment and the great challenge is to adapt animal production to the population's demand and at the same time to maintain sustainability (Lucas Júnior and Amorim, 2005). This fact became a central point of current discussions in several production chains, as the studies on composting, vermicomposting and anaerobic biodigestion techniques demonstrate, as they relate to aspects of sanitation, energy and nutrient recycling (Orrico Júnior et al., 2011; Martins and Oliveira, 2011). The use of biodigestors in animal production systems is important, because in addition to promoting the treatment of waste, they generate energy that can keep the production system energetically balanced (Orrico Júnior et al., 2011; Martins and Oliveira, 2011). 
The results highlight a large number of publications involving biodigestion with swine manure. In fact, national pig farming is well established, and Brazil ranks $4^{\text {th }}$ in the world in production and export of pork. According to Rizzoni et al. (2012) and Moraes et al. (2016), pig farming is considered by environmental control agencies to be the agricultural activity that results in greater environmental impact.

Lucas Júnior and Amorim (2005) reported that pig farming waste is mainly composed of animal manure, feed residue and water. Ensminger et al. (1990), when considering an animal unit (450 kg body weight), found that pigs excreted 1.9 times more waste than beef cattle and 1.3 times more waste than dairy cattle, evidencing the high waste generation in the activity; in comparative terms, it is equivalent to four times that of the human population. The growing expansion of this activity highlights the need for studies on the proper disposal of waste and residues from this chain.

In agreement with Esperancini et al. (2007), there are several technological alternatives that involve the use of biomass for energy generation and the anaerobic biodigestion of animal waste has attracted great interest, mainly from pig farming.

Industrial pig farming generates large quantities of effluents that require treatment; thus, the anaerobic biodigestion process is an important, low-cost and efficient treatment for the reduction of organic matter in wastewater from pig farming (Amaral et al., 2004; Vivian et al., 2010; Moraes et al., 2016). But the efficiency of anaerobic processes is limited, among other ways, by the concentration of volatile solids in the biodigester and their capacity to mineralize organic matter over hydraulic retention time (Amaral et al., 2004).

The use of beef cattle waste as a substrate for biodigestion was $2^{\text {nd }}$ in the number of publications. This result is curious because the amount of material excreted by these animals is on average $24 \mathrm{~kg} /$ day (Ensminger et al., 1990) and the main form of production is widely spread out (Oliveira et al., 2010), making it difficult to collect and use this material in biodigestion.

Nevertheless, despite the reduced number of articles with dairy cows, biodigestion for waste of this animal category is more indicated, since the amount of excreted material is greater, on average, $40 \mathrm{~kg} /$ day/cow and most of the production occurs in feedlot systems (Oliveira et al., 2010). These records evidenced the greater energetic potential of dairy cattle in relation to beef cattle; also, Orrico et al. (2016) verified that the addition of 4.4 and $6.5 \%$ of discarded oil to substrates containing dairy cattle waste increases the biogas production even further.

Consistent with the need to search for correct disposal, Law 12,305, which instituted the National Solid Waste Policy (Brasil, 2010), lists as environmentally friendly final disposals: reuse, recycling, composting, recovery and energy utilization, among others. Therefore, publications on biodigestion using animal waste, especially from pig and beef cattle, which are expressively farmed in Brazil, are relevant and necessary at the present time.

Of the total number of publications, it is possible to observe that the State of São Paulo contributed $34.34 \%$ of all published studies; Paraná ranks second, with $20.20 \%$, followed by Minas Gerais, with $13.13 \%$. Five brazilian publications (5\% of the total) belong to authors from Italy (Raboni and Urbini, 2014 and Raboni et al., 2015), Chile (Ortiz et al., 2014), Argentina (Fuentes et al., 2009) and Colombia (Cañon-Franco et al., 2012). This finding shows that the Brazilian journals are well-referenced, with a high impact factor and high JCR in the area of environmental sciences, since outside the country the quality of production is measured by means of these two indices.

In Brazil, the quality of intellectual production is identified in the Qualis stratum through the analysis of scientific journals (CAPES, 2011). Considering this evaluation criterion, it was possible to observe that $87.88 \%$ of the published scientific articles come from scientific journals classified with higher strata, evidencing the high level of the research. 


\section{CONCLUSION}

The quantitative evaluation showed a reduced number of publications on biodigestion in the historical series between 1985 and 2015.

Most of the works are recent and the most common theme investigated in recent years is the energy issue and the production of biogas, in addition to environmentally friendly waste management.

Many publications dealt with the general evaluation of the process, using mainly pig manure as substrate.

The State of São Paulo stood out with the largest number of articles published; the majority in periodicals with high CAPES Qualis in the area of Environmental Sciences.

\section{REFERENCES}

ALTA, C.; FRIOS, M. R. Atividade microbiana do solo com a aplicação de esterco bovino e efluente de biodigestor. Ciência Rural, v. 22, n. 2, p. 161-165, 1992. http://dx.doi.org/10.1590/S0103-84781992000200007

AMARAL, C. M. C.; AMARAL, L. A.; LUCAS JÚNIOR, J.; NASCIMENTO, A. A.; FERREIRA, D. S.; MACHADO, M. R. F. Biodigestão anaeróbia de dejetos de bovinos leiteiros submetidos a diferentes tempos de retenção hidráulica. Ciência Rural, v. 34, n. 6, p.1897-1902, 2004. http://dx.doi.org/10.1590/S0103-84782004000600035

BASSO, L. H.; SOUZA, S. N. M.; SIQUEIRA, J. A. C.; NOGUEIRA, C. E. C.; SANTOS, R. F. Análise de um sistema de aquecimento de água para residências rurais, utilizando energia solar. Engenharia Agrícola, v. 30, n. 1, p.14-21, 2010. http://dx.doi.org/10.1590/S0100-69162010000100002

BRASIL. Lei $\mathrm{n}^{\circ}$ 12.305, de 2 de agosto de 2010. Institui a Política Nacional de Resíduos Sólidos; altera a Lei no 9.605, de 12 de fevereiro de 1998; e dá outras providências. Diário Oficial da União, Brasília, DF, 2 ago. 2010.

BÓCOLI, M. E.; MANTOVANI, J. R.; MIRANDA, J. M.; MARQUES, D. J.; SILVA, A. B. Soil chemical properties and maize yield under application of pig slurry biofertilizer. Revista Brasileira de Engenharia Agrícola e Ambiental, v. 20, n. 1, p. 42-48, 2016. http://dx.doi.org/10.1590/1807-1929/agriambi.v20n1p42-48

BRAUN, T.; SCHUBERT, A. Scientometric versus socio-economic indicators. Scatter plots for 51 countries, 1978-1980. Scientometrics, v. 13, n. 1/2, p. 3-9, 1988. http://dx.doi.org/10.1007/BF02095758

CAÑON-FRANCO, W. A.; HENAO-AGUDELO, R. A.; PÉREZ-BEDOYA, J. L. Recovery of gastrointestinal swine parasites in anaerobic biodigester systems. Revista Brasileira de Parasitologia Veterinária, v. 21, n. 2, p. 249-253, 2012. http://dx.doi.org/10.1590/S1984-29612012000300013

COORDENAÇÃO DE APERFEIÇOAMENTO DE PESSOAL DE NÍVEL SUPERIOR CAPES. Classificação da produção intelectual. 16 ago. 2016. Available in: https://goo.gl/N1fJTG. Access in: November 2015.

COORDENAÇÃO DE APERFEIÇOAMENTO DE PESSOAL DE NÍVEL SUPERIOR CAPES. Diretoria de Avaliação - DAV. Minuta do documento de área 2011- ciência ambientais. Brasília, 2011. Available in: https://goo.gl/qmLq4f. Access in: September 2015 . 
EL-MASHAD, H. M.; ZHANG, R. Biogas production from co-digestion of dairy manure and food waste. Bioresource Technology, v. 101, p. 4021-4028, 2010. https://doi.org/10.1016/j.biortech.2010.01.027

ENSMINGER, M. E.; OLDFIELD, J. E.; HEINEMANN, W. W. Feeds \& Nutrition. 2. ed. Clovis: The Ensminger Publishing Company, 1990. 1544 p.

ESPERANCINI, M. S. T.; COLEN, F.; BUENO, O. C.; PIMENTEL, A. E. B.; SIMON, E. J. Viabilidade técnica e econômica da substituição de fontes convencionais de energia por biogás em assentamento rural do Estado de São Paulo. Engenharia Agrícola, v. 27, n. 1, p. 110-118, 2007. http://dx.doi.org/10.1590/S0100-69162007000100004

FUENTES, M.; MUSSATI, M. C.; AGUIRRE, P. A.; SCENNA, N. J. Experimental and theoretical investigation of anaerobic fluidized bed biofilm reactors. Brazilian Journal

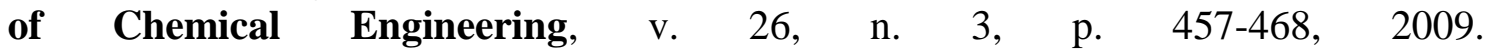
http://dx.doi.org/10.1590/S0104-66322009000300002

GOMES, A. C. A.; ROCHA, M. M.; GALVÃO, A. S.; ALBINO, P. M. B. Incentivos para a viabilização do biogás a partir dos resíduos da pecuária leiteira no Estado de Minas Gerais. Desenvolvimento e Meio Ambiente, v. 30, p. 149-160, 2014.

KUNZ, A.; OLIVEIRA, P. A. V. Uso de biodigestores para tratamento de resíduos animais. Concórdia: Embrapa Suínos e Aves, 2008.

LACERDA, T. H. M.; OLIVEIRA, A. J.; CARUSO, J. G. B. Viabilidade do tratamento do soro de queijo com digestão anaeróbia. Anais da Escola Superior Agrícola Luiz de Queiroz, v. 47, n. 2, p. 557-573, 1990. http://dx.doi.org/10.1590/S0071-12761990000200016

LEAL, R. M. P.; FIRME, L. P.; HERPIN, F.; MONTES, C. R.; DIAS, C. T. S.; MELFI, A. J. Carbon and nitrogen cycling in a tropical Brazilian soil cropped with sugarcane and irrigated with wastewater. Agricultural Water Management, v. 97, p. 271-276, 2010. https://doi.org/10.1016/j.agwat.2009.09.018

LUCAS JUNIOR, J.; AMORIM, A. C. Manejo de dejetos: fundamentos para a integração e agregação de valor. In: ZOOTEC, 2005, 24-27 maio 2005, Campo Grande. Anais... Campo Grande: UEMS, 2005. 33 p.

MANFRON, M. P. Biodigestão anaeróbica: uma alternativa para usinas de laticínios. Ciência e Cultura, v. 21, p. 145-152, 1991.

MARTINS, F. M.; OLIVEIRA, P. A. V. Análise econômica da geração de energia elétrica a partir do biogás na suinocultura. Engenharia Agrícola, v. 31, n. 3, p. 477-486, 2011. http://dx.doi.org/10.1590/S0100-69162011000300008

MORAES, R.; KUNZ, A.; STEFFENS, J.; DALLAGO, R. M.; BENAZZI, T. L.; AMARAL, A. C. Swine manure digestate treatment using electrocoagulation. Scientia Agricola, v. 73, n. 5, p. 439-443, 2016. http://dx.doi.org/10.1590/0103-9016-2015-0269

OLIVEIRA, L. A.; MARQUES, F. S.; HOEPERS, A. Dimensionamento do potencial de geração distribuída pela biomassa animal residual na bacia do Paraná 3 . Foz do Iguaçu: ADEOP, 2010.

ORRICO, A. C. A.; LOPES, W. R. T.; MANARELLI, D. M.; ORRICO JUNIOR, M. A. P; SUNADA, N. S. Codigestão anaeróbia dos dejetos de bovinos leiteiros e óleo de descarte.

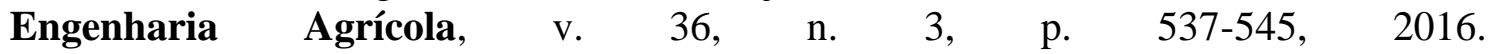
http://dx.doi.org/10.1590/1809-4430-Eng.Agric.v36n3p537-545/2016 
ORRICO JÚNIOR, M. A. P.; ORRICO, A. C. A.; LUCAS JÚNIOR, J. Produção animal e o meio ambiente: uma comparação entre potencial de emissão de metano dos dejetos e a quantidade de alimento produzido. Engenharia Agrícola, v. 31, n. 2, p. 399-410, 2011. http://dx.doi.org/10.1590/S0100-69162011000200020

ORTIZ, G.; VILLAMAR, C. A.; VIDAL, G. Odor from anaerobic digestion of swine slurry; influence of pH, temperature and organic loading. Scientia Agricola, v. 71, n. 6, p. 443450, 2014. http://dx.doi.org/10.1590/0103-9016-2013-0372

PALHARES, J. C. P. Biodigestão anaeróbia de dejetos de suínos: aprendendo com o passado para entender o presente e garantir o futuro. Infobibos, 2008. Available in: http://www.infobibos.com/Artigos/2008_1/Biodigestao/index.htm. Access in: Octuber 2015.

PRADA, S. M.; GUEKEZIAN, M.; SUÁREZ-IHA, M. E. Metodologia analítica para a determinação de sulfato em vinhoto. Química Nova, v. 21, n. 3, p. 249-253, 1998. http://dx.doi.org/10.1590/S0100-40421998000300002

RABONI, M.; URBINI, G. Production and use of biogás in Europe: a survey os current status and perspectives. Revista Ambiente \& Água, v. 9, p. 191-202, 2014. http://dx.doi.org/10.4136/ambi-agua.1324

RABONI, M.; VIOTTI, P.; CAPODAGIO, A. G. A comprehensive analysis of the current and future role of biofuels for transport in the European Union (EU). Revista Ambiente \& Água, v. 10, p. 9-21, 2015. http://dx.doi.org/10.4136/ambi-agua.1492

RIZZONI, L. B.; TOBIAS, A. C. T.; DEL BIANCHI, M.; GARCIA, J. A. D. Biodigestão anaeróbia no tratamento de dejetos de suínos. Revista Científica Eletrônica de Medicina Veterinária, v. 9, n. 18, p. 1-20, 2012.

ROCHA, G. O.; ANDRADE, J. B.; GUARIEIRO, A. L. N., GUARIEIRO, L. L. N.; RAMOS, L. P. Química sem fronteiras: o desafio da energia. Química Nova, v. 36, n. 10, p. 15401551, 2013. http://dx.doi.org/10.1590/S0100-40422013001000010

SAWAZAKI, H. E.; FEIJÃO, J. P.; MORAES, R. M. O pH e a temperatura na produção de biogás a partir da casca de arroz. Bragantia, v. 44, p. 715-721, 1985. http://dx.doi.org/10.1590/S0006-87051985000200019

SILVA, W. T. L. Avaliação físico-química de efluente gerado em biodigestor anaeróbio para fins de avaliação de eficiência e aplicação como fertilizante agrícola. Química Nova, v. 35, n. 1, p. 35-40, 2012. http://dx.doi.org/10.1590/S0100-40422012000100007

STREHL, L.; SANTOS, C. A. Indicadores de qualidade da atividade científica. Ciência Hoje, v. 31, n. 186, p. 34-39, 2002.

VANTI, N. A. P. Da bibliometria à webometria: uma exploração conceitual dos mecanismos utilizados para medir o registro da informação e a difusão do conhecimento. Ciência da Informação, v. 31, n. 2, p. 152-162, 2002. http://dx.doi.org/10.1590/S010019652002000200016

VIVIAN, M.; KUNZ, A.; STOLBERG, J.; PERDOMO, C.; TECHIO, V. H. Eficiência da interação biodigestor e lagoas de estabilização na remoção de poluentes em dejetos de suínos. Revista Brasileira de Engenharia Agrícola e Ambiental, v. 14, n. 3, p. 320325, 2010. http://dx.doi.org/10.1590/S1415-43662010000300013 